\title{
Effects of low-level laser therapy on stem cells from human exfoliated deciduous teeth
}

\author{
Ana Paula FERNANDES'1, Marina de Azevedo JUNQUEIRA², Nádia Carolina Teixeira MARQUES', Maria Aparecida \\ Andrade Moreira MACHADO', Carlos Ferreira SANTOS ${ }^{3}$, Thais Marchini OLIVEIRA ${ }^{1}$, Vivien Thiemy SAKAl ${ }^{2}$

\footnotetext{
1- Universidade de São Paulo, Faculdade de Odontologia de Bauru, Departamento de Odontopediatria, Ortodontia e Saúde Coletiva, Bauru, SP, Brasil.

2- Universidade Federal de Alfenas, Departamento de Clínica e Cirurgia, Alfenas, MG, Brasil.

3- Universidade de São Paulo, Faculdade de Odontologia de Bauru, Departamento de Ciências Biológicas, Bauru, SP, Brasil.
}

Corresponding address: Thais Marchini Oliveira - Departamento de Odontopediatria, Ortodontia e Saúde Coletiva - Faculdade de Odontologia de Bauru Universidade de São Paulo - Alameda Dr. Octávio Pinheiro Brisolla, 9-75 - 17012-901 - Bauru - SP- Brazil - Phone: 551432358224 - e-mail: marchini@usp.br

Submitted: June 12, 2015 - Modification: February 24, 2016 - Accepted: March 1, 2016

\section{ABSTRACT}

ow-Level Laser Therapy stimulates the proliferation of a variety of types of cells. However, -very little is known about its effect on stem cells from human exfoliated deciduous teeth (SHED). Objective: This study aimed to evaluate the influence of different laser therapy energy densities on SHED viability and proliferation. Material and Methods: SHED were irradiated according to the groups: I $\left(1.2 \mathrm{~J} / \mathrm{cm}^{2}-0.5 \mathrm{~mW}-10 \mathrm{~s}\right)$, II $\left(2.5 \mathrm{~J} / \mathrm{cm}^{2}-10\right.$ $\mathrm{mW}-10 \mathrm{~s})$, III $\left(3.7 \mathrm{~J} / \mathrm{cm}^{2}-15 \mathrm{~mW}-10 \mathrm{~s}\right)$, IV $\left(5.0 \mathrm{~J} / \mathrm{cm}^{2}-20 \mathrm{~mW}-10 \mathrm{~s}\right), \mathrm{V}(6.2 \mathrm{~J} /$ $\mathrm{cm}^{2}-25 \mathrm{~mW}-10 \mathrm{~s}$ ), and VI (not irradiated - control group). Cell viability was assessed 6 and $24 \mathrm{~h}$ after irradiation measuring the mitochondrial activity and using the Crystal Violet assay. Cell proliferation was assessed after 24, 48, and $72 \mathrm{~h}$ of irradiation by SRB assay. Results: MTT assay demonstrated differences from 6 to 24 hours after irradiation. After $24 \mathrm{~h}$, groups I and IV showed higher absorbance values than those of control group. Crystal Violet assay showed statistically differences in the absorbance rate from 6 to 24 $\mathrm{h}$ after irradiation for groups III and VI. At $24 \mathrm{~h}$ after irradiation, Group III absorbance rate was greater than that of groups I, II, and IV. Group VI absorbance rate was greater than that of groups I and IV. SRB assay showed that the group I had higher rates than those of groups II, III, V, and VI, at $24 \mathrm{~h}$ after irradiation. After $48 \mathrm{~h}$, group I exhibited the greatest cell proliferation rate followed by groups III, V, and VI. After $72 \mathrm{~h}$, group III exhibited the lowest cell proliferation rate than those of groups II, IV, and V. Conclusions: The Low-Level Laser Therapy energy densities used in this study did not cause loss of cell viability and stimulated SHED proliferation within the parameters described in this study.

Keywords: Lasers. Stem cells. Deciduous tooth.

\section{NTRODUCTION}

Tissue engineering with the triad of dental pulp stem cells, morphogens, and scaffolds may provide a useful alternative method for pulp-capping and root canal treatment ${ }^{23}$. The use of stem cells from human exfoliated deciduous teeth (SHED) might bring advantages for tissue engineering mainly because SHED was reported to have higher proliferation rate and increased cell population doublings, and they are retrieved from a tissue that is readily accessible in young patients. Additionally, previous studies proposed that dental pulp tissue engineering with stem cells could be ideally suited for dentin regeneration in response to noxious stimuli, such as caries ${ }^{16}$, and for young patients who have suffered pulp necrosis in immature permanent incisors as a consequence of trauma ${ }^{8}$.

The ability of Low-Level Laser Therapy (LLLT) to stimulate the proliferation of a variety of cell types has been considered as its most important physiological effect ${ }^{27}$. Studies have shown that LLLT promotes an increase in the proliferation rate of cells such as fibroblast ${ }^{15,21}$, endothelial cells ${ }^{21}$, osteoblasts ${ }^{13}$, epithelial cells ${ }^{11}$, and lymphocytes ${ }^{6}$. Concerning the proliferation of mesenchymal stem cells, a positive effect of LLLT on bone marrow ${ }^{30}$ and adipose tissue stem cells has been reported in literature ${ }^{22}$. However, 
very little is known about the effect of laser therapy on dental pulp stem cells. Therefore, this study aimed to evaluate the effect of LLLT on the viability and proliferation of SHED.

\section{MATERI AL AND METHODS}

\section{Cell culture}

Stem cells from human exfoliated deciduous teeth, gently provided by Dr. Bruno N. Cavalcanti (DDS, MSc, PhD, Institute of Science and Technology, São Paulo State University, São José dos Campos, $\mathrm{SP}$, Brazil), were isolated by standard enzymatic digestion protocol and characterized according to Miura, et al. ${ }^{20}$ (2003) after Institutional Review Board approval (CAAE 02210312.1.0000.0077). The SHED were maintained in alpha modification of Eagle medium (MEMa, Invitrogen, Carlsbad, California) culture medium supplemented with $10 \%$ fetal bovine serum (FBS - Fetal Bovine Serum, Certified, Heat-inactivated, Gibco, Invitrogen, Grand Island, New York, United States) and $1 \%$ penicillin and streptomycin solution (Penicillin-Streptomycin, Gibco, Invitrogen, Grand Island, New York, United States). Cells were maintained in an incubator at $37^{\circ} \mathrm{C}$ and $5 \% \mathrm{CO}_{2}$ and split at a ratio of $1: 3$ when they reached $80 \%$ of confluence. The medium was changed every two days. For all experiments, SHED at passages 4 to 8 was used.

\section{Experimental groups}

The cultures were divided into six groups according to the LLLT energy density of irradiation: I $\left(1.2 \mathrm{~J} / \mathrm{cm}^{2}-0.5 \mathrm{~mW}-10 \mathrm{~s}\right)$, II $\left(2.5 \mathrm{~J} / \mathrm{cm}^{2}-10\right.$ $\mathrm{mW}-10 \mathrm{~s})$, III $\left(3.7 \mathrm{~J} / \mathrm{cm}^{2}-15 \mathrm{~mW}-10 \mathrm{~s}\right)$, IV (5.0 $\left.\mathrm{J} / \mathrm{cm}^{2}-20 \mathrm{~mW}-10 \mathrm{~s}\right), \mathrm{V}\left(6.2 \mathrm{~J} / \mathrm{cm}^{2}-25 \mathrm{~mW}-10\right.$ $\mathrm{s})$, and VI (not irradiated - control group).

\section{Low-levell laser therapy irradiation}

Stem cells from human exfoliated deciduous teeth were seeded in 96 -well plates $\left(1 \times 10^{4}\right.$ cells/well) with alpha-MEM supplemented with $10 \%$ FBS and allowed to attach overnight. Prior to laser irradiation, the media of all wells were replaced by fresh culture medium supplemented with $1 \% \mathrm{FBS}^{9}$, and then the plates were wrapped in a mask composed of black cardboard with holes located in the position of the wells of the experimental groups. Each hole was individually sealed by a hatch, also in black cardboard that allowed only the bore of the well that was being irradiated to remain open, while all the others were kept in the dark. The holes in the mask had the diameter of $0.5 \mathrm{~cm}^{2}$, while the laser spot had the diameter of $0.4 \mathrm{~cm}^{2}$. LLLT irradiation was made through the transparent bottom of the 96-well plates, keeping the distance between the light beam and the cell monolayer constant at $1 \mathrm{~mm}$. Therefore, the radiation passed directly to the cell monolayer via the plate base without travelling through the culture medium reaching the cells, following the methodology previously adopted ${ }^{3,11,29}$. The power of the laser was measured with the Lasercheck PowerMeter (Coherent Inc., Santa Clara, California) prior to each application. Aluminium-gallium-indium-phosphide (InGaAIP) Lowlevel Laser (Twin Flex Evolution MMOptics ${ }^{\circledR}$ - São Carlos, SP, Brazil) was employed in all groups at wavelength of $660 \mathrm{~nm}$ (red); output beam area of $0.04 \mathrm{~cm}^{2}$, and varying the energy density in function of the power used for each experimental group. The control group was treated under identical conditions except that the laser device was kept off. After irradiation, the media of all wells were replaced by fresh culture medium supplemented with $10 \%$ FBS.

\section{MTT assay}

Aiming to evaluate the cytotoxicity of the different LLLT irradiation densities, 3-(4, 5-dimethyl-2thiazolyl) -2, 5-diphenyl -2H-tetrazolium bromide (MTT) assay was performed after 6 and 24 hours of irradiation. At the end of the respective incubation time, the supernatants were discarded and $200 \mu \mathrm{L}$ MTT solution was added into each well to a final concentration of $5 \mathrm{mg} / \mathrm{mL}$. After an additional 4-hour incubation period, the supernatant was discarded, and $200 \mu \mathrm{L}$ dimethyl sulfoxide (DMSO, Fisher Scientific, Hampton, New Hampshire, United States) was added to solubilize the formazan crystals. Immediately, the absorbance was read in a microplate reader (Zenyth, $200 \mathrm{RT}$, Anthos) at $560 \mathrm{~nm}^{7}$. Data were obtained from three wells per condition.

\section{Crystall violet assay}

The crystal violet assay is useful for obtaining quantitative information about the relative density of cells adhering to multiwell cluster plates ${ }^{12}$. Crystal violet solution is capable of assessing cellular viability because it stains cellular DNA of living cells. SHED were irradiated and then incubated at $37^{\circ} \mathrm{C}, 5 \% \mathrm{CO}_{2}$, and divided into $1: 3$ rates when reaching to $80 \%$ confluence. The medium was changed every two days. At the end of incubation, supernatants were discarded and crystal violet solution was added into the wells. Then, the plates were incubated at $37 \%$, $5 \% \mathrm{CO}_{2}$ for 6 and $24 \mathrm{~h}$. Cell platting was similar to that of the MTT assay regarding steps, periods, and cell amounts. All culture media was removed from the plate, including the Blank and control groups. Next, each well was washed with PBS (200 uL). Following, 100\% methanol (200 uL) was used for $10 \mathrm{~min}$. Elapsed that time, methanol was removed and crystal violet solution (200 uL) was added to the wells for $3 \mathrm{~min}$. Following, crystal violet solution was removed, and each well was washed with PBS $1 \times(200 \mathrm{uL})$ twice. Then, sodium citrate $0.05 \mathrm{~mol} . \mathrm{L}$ (200 uL) was added for $10 \mathrm{~min}$. The absorbance reading was performed in spectrophotometer at 570 
$\mathrm{nm}$ wavelength. Negative controls (Blank) were wells without cells.

\section{SRB assay}

Cell proliferation by Sulforhodamine B (SRB) assay was assessed after 24, 48, and 72 hours of irradiation. At the end of the respective incubation time, cells were fixed by the addition of $10 \%$ trichloroacetic acid and incubated for 1 hour at $4^{\circ} \mathrm{C}$. Plates were washed in tap water five times and allowed to dry. Cellular protein was stained by adding 4\% SRB in 1\% acetic acid and incubated at room temperature for 30 minutes. Excess SRB was removed by washing the wells with $1 \%$ acetic acid and remaining SRB was solubilized in $10 \mathrm{mM}$ Trisbase unbuffered. Absorbance was determined on a spectrophotometer at a wavelength of $565 \mathrm{~nm}^{18,26}$. Data were obtained from three wells per condition.

\section{Statistical analysis}

Statistical analysis was performed using $\mathrm{R}$ Statistical Software. Viability and proliferation data were analyzed by two-way analysis of variance (ANOVA), followed by Tukey's test. Differences were considered significant at $p<0.05$. Data were expressed as mean value and standard deviation.

\section{RESULTS}

\section{MTT assay}

All groups except for group I showed statistically significant differences in the absorbance rate from 6 to 24 hours after irradiation. At 6 hours after irradiation, group I exhibited the greatest absorbance value as compared with those of the other groups. At 24 hours after irradiation, both group I and IV showed higher absorbance values than that of the control group (VI). Group IV also showed higher absorbance value than those of groups II and V, and this difference was statistically significant $(p<0.05)$ (Figure 1).

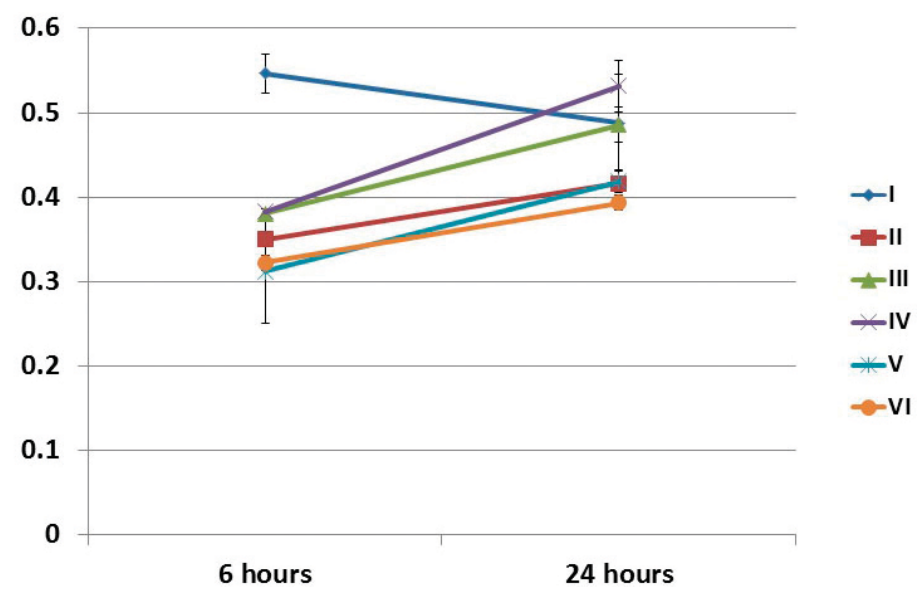

Figure 1- Cell viability (MTT assay) of SHED regarding the time after irradiation and experimental groups.

I $\left(1.2 \mathrm{~J} / \mathrm{cm}^{2}-0.5 \mathrm{~mW}-10 \mathrm{~s}\right)$, II $\left(2.5 \mathrm{~J} / \mathrm{cm}^{2}-10 \mathrm{~mW}-10 \mathrm{~s}\right)$, III $\left(3.7 \mathrm{~J} / \mathrm{cm}^{2}-15 \mathrm{~mW}-10 \mathrm{~s}\right)$, IV $\left(5.0 \mathrm{~J} / \mathrm{cm}^{2}-20 \mathrm{~mW}-10 \mathrm{~s}\right)$, $\mathrm{V}\left(6.2 \mathrm{~J} / \mathrm{cm}^{2}-25 \mathrm{~mW}-10 \mathrm{~s}\right)$, and $\mathrm{VI}$ (not irradiated - control group)

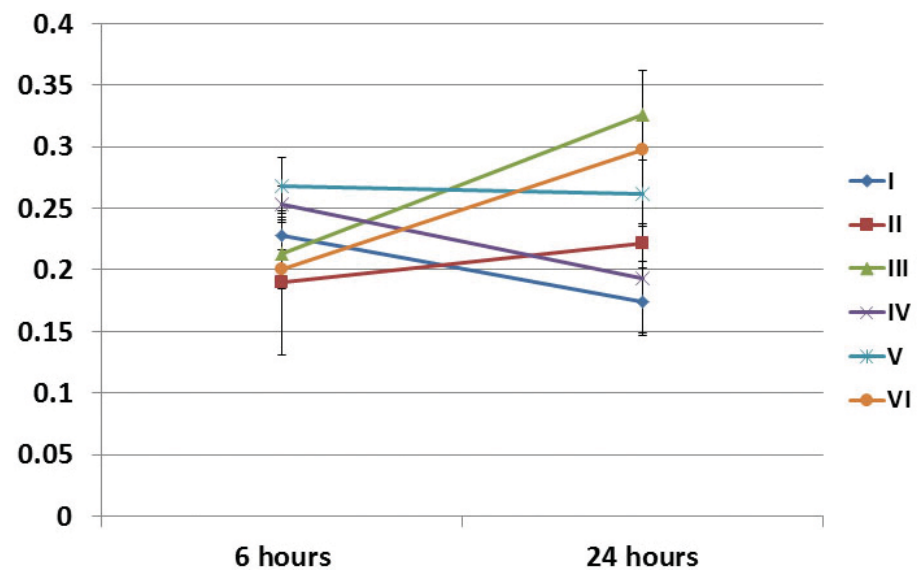

Figure 2- Cell viability (Crystal violet assay) of SHED regarding the time after irradiation and experimental groups.

I (1.2 J/cm² - $0.5 \mathrm{~mW}-10 \mathrm{~s})$, II $\left(2.5 \mathrm{~J} / \mathrm{cm}^{2}-10 \mathrm{~mW}-10 \mathrm{~s}\right)$, III $\left(3.7 \mathrm{~J} / \mathrm{cm}^{2}-15 \mathrm{~mW}-10 \mathrm{~s}\right)$, IV $\left(5.0 \mathrm{~J} / \mathrm{cm}^{2}-20 \mathrm{~mW}-10 \mathrm{~s}\right)$, $\mathrm{V}\left(6.2 \mathrm{~J} / \mathrm{cm}^{2}-25 \mathrm{~mW}-10 \mathrm{~s}\right)$, and VI (not irradiated - control group) 


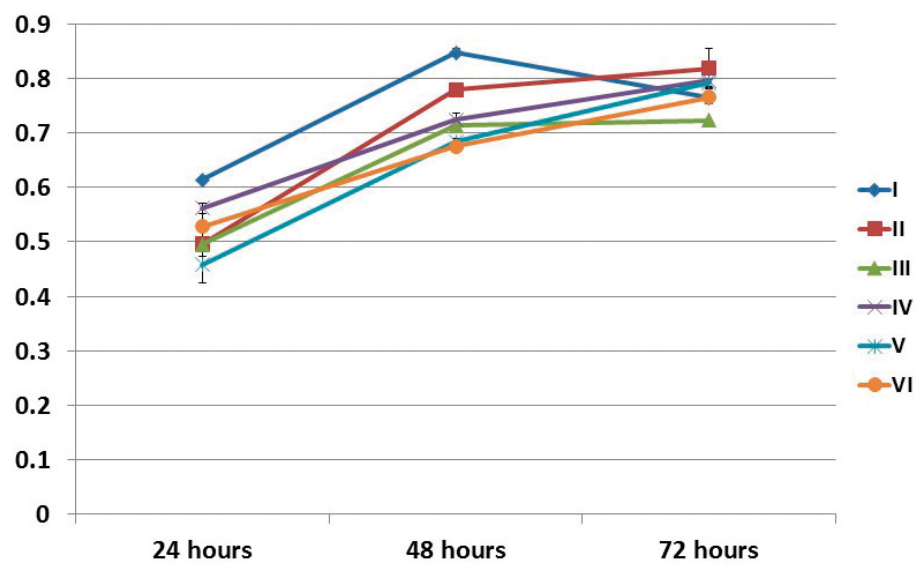

Figure 3- Cell proliferation (SRB assay) of SHED regarding the time after irradiation and experimental groups.

I (1.2 J/cm² - $0.5 \mathrm{~mW}-10 \mathrm{~s})$, II $\left(2.5 \mathrm{~J} / \mathrm{cm}^{2}-10 \mathrm{~mW}-10 \mathrm{~s}\right)$, III $\left(3.7 \mathrm{~J} / \mathrm{cm}^{2}-15 \mathrm{~mW}-10 \mathrm{~s}\right)$, IV $\left(5.0 \mathrm{~J} / \mathrm{cm}^{2}-20 \mathrm{~mW}-10 \mathrm{~s}\right)$, $\mathrm{V}\left(6.2 \mathrm{~J} / \mathrm{cm}^{2}-25 \mathrm{~mW}-10 \mathrm{~s}\right)$, and VI (not irradiated - control group)

\section{Crystal violet assay}

Groups III and VI showed statistically significant differences in the absorbance rate from 6 to 24 hours after irradiation. At 6 hours after irradiation, there was no statistical difference between groups. At 24 hours after irradiation, group III absorbance rate was greater than that of groups I, II, and IV. The positive control absorbance rates were greater than those of groups I and IV (Figure 2).

\section{SBR assay}

At 24 hours after irradiation, group I showed statistically significant higher cell proliferation than groups II, III, V, and VI. At 48 hours after irradiation, group I exhibited the greatest cell proliferation compared with the other groups, and group II showed higher cell proliferation than groups III, V, and VI, with statistically significant difference. At 72 hours after irradiation, group III exhibited statistically significant lower cell proliferation than groups II, IV, and $\mathrm{V}$ (Figure 3).

\section{DISCUSSION}

The biostimulatory effect of LLLT has been reported for at least four decades. Since this effect was first reported, researchers in this field have sought to determine the best laser protocol to promote the reported positive biostimulatory effects attributed to low energy irradiation. However, studies investigating this effect of LLLT on dental stem cells are scarce in the literature and there are no reports on stem cells from human exfoliated deciduous teeth. By submitting cells to LLLT, some authors reported higher proliferation rates of gingival fibroblasts ${ }^{9}$, dental pulp stem cells from permanent teeth ${ }^{10}$, and stem cells derived from bone marrow and adipose tissue $^{4,27}$. It has been suggested that the energy of the laser is absorbed by intracellular chromophores and converted into metabolic energy, which is then used by the mitochondrial respiratory chain to produce ATP and increasing DNA activity and the synthesis of RNA and proteins.

AlGhamdi, et al. ${ }^{1}$ (2012) affirmed that, for biological effects, laser wavelengths may be red or near infrared (600-1200 nm), and for biostimulatory effects, energy fluences may range from 0.05 to 10 $\mathrm{J} / \mathrm{cm}^{2}$ to induce cell proliferation, whereas energies greater than this value $\left(>10 \mathrm{~J} / \mathrm{cm}^{2}\right)$ may promote antiproliferative effects. In this present study, the wavelengths were set at $660 \mathrm{~nm}$ (red laser) and different energy densities were established in relation to the Irradiation Time in function of the Power, according to the experimental group. The energy density may be important to reach an improvement in cell growth ${ }^{25}$. Notwithstanding, the effect of energy density variation is still unknown, mainly on pulp cells of human primary teeth. Many studies have tested different energy densities ${ }^{1,5,14}$ and, according to some authors, the energy densities ranging from 0.5-4 J/ $\mathrm{cm}^{2}$ have been more effective in stimulating cellular growth ${ }^{1,2,5,19,24,29}$. According to Karu, et al. ${ }^{17}$ (1987), the dose increase damages photoreceptors, which reduces the biomodulatory effect of the laser as a result of the inhibition of metabolism and consequent cell death. In this study, for MTT assay, the lowest dose, group I $\left(1.2 \mathrm{~J} / \mathrm{cm}^{2}\right)$, showed the more favorable results on cell viability as much as 6 to 24 hours after irradiation compared with the others groups. For Crystal Violet assay, the group III $\left(3.7 \mathrm{~J} / \mathrm{cm}^{2}\right)$ showed the more favorable results at 24 hours after irradiation.

Concerning cell proliferation, group I also exhibited the best cell proliferation rate mainly at 24 and 48 hours after irradiation compared with that of the control group. The group $\mathrm{V}$ was the group with the result more similar to that of the non-irradiated group. The results are in agreement with the studies of Barboza, et al. ${ }^{4}$ (2014), who irradiated bone marrow and adipose tissue derived from mesenchymal stem 
cells, and Stein, et al. ${ }^{28}$ (2005), who irradiated human osteoblasts. Both authors had higher cell proliferation using a wavelength of $670 \mathrm{~nm}$ and a dose of $1.0 \mathrm{~J} /$ $\mathrm{cm}^{2}$ at the first 72 hours after irradiation.

Regarding the concern of the appropriate serum, additional Crystal Violet assay was performed in order to compare cell viability after irradiation of SHED growing in medium supplemented with either $1 \%$ FBS or $10 \%$ FBS. After 6 hours of irradiation, the absorbance rates of cells growing in the different serum concentration media were statistically similar for all the irradiation doses evaluated. However, after 24 hours, higher values were observed for those cells growing in medium supplemented with $1 \%$ FBS in comparison with $10 \%$ FBS for all of the doses (data not shown). These data support our experiments with the low concentration of FBS, which seems to be the most appropriate serum concentration to show the effect of laser phototherapy in SHED. The mechanism of cellular stress occurs because of alterations triggered by oxidant agents, temperature, and nutritional deficiency of the culture medium. The decrease in the concentration of the fetal bovine serum in the culture medium (nutritional deficit) has been efficiently used to evaluate the effects of low level laser irradiation on cellular metabolism ${ }^{2,9,10}$. In this present study, after plating on Alpha Modification of Eagle medium supplemented with $10 \%$ FBS, the cells were incubated for $24 \mathrm{~h}$ until reaching a subconfluent state in the wells. Elapsed that period, all wells received a medium supplemented with $1 \%$ FBS, in such a way that the cells reach the quiescence state stage at the moment of the irradiation?.

The study of Ginani, et al. ${ }^{14}$ (2015) evaluated the literature on the effect of low level laser on stimulating mesenchymal stem cells from 2002 to 2013 and found that the laser parameters ranged in relation to the wavelength both in visible (red) and invisible (infrared) light, but no study compared the effects of the two wavelengths (red and infrared) on cellular proliferation. Concerning the dose, most of the studies used $0.5 \mathrm{~J} / \mathrm{cm}^{2}$, ranging from $0.05 \mathrm{~J} / \mathrm{cm}^{2}$ to $42 \mathrm{~J} / \mathrm{cm}^{2}$. The laser power varied in the different light spectrum: for visible light, power ranged from $0.02 \mathrm{~mW}$ to $119 \mathrm{~mW}$; for invisible light from $50 \mathrm{~mW}$ to $800 \mathrm{~mW}$. The effect of low level laser intensity has been evaluated on the proliferation of the mesenchymal stem cells of different tissues: bone marrow, dental pulp, and periodontal ligament. The authors concluded that greater proliferation occurred in mesenchymal stem cells from bone marrow and adipose tissue after applying low level laser, but further studies on mesenchymal stem cells from dental tissues are necessary. Finally, it is necessary to standardize the low level laser parameters, improving not only the comparison of the results but also the results themselves. Basso, et al. ${ }^{5}$ (2012) affirmed that determining the parameter and ideal techniques of irradiation is mandatory to develop further studies to verify the potential and adequate biostimulatory effect of LLLT. Consequently, the knowledge of the proper combination of these parameters (e.g., wavelength, power density, and energy density) is required to reach the desirable effects of the treatments.

The search for solutions and ideal materials in any knowledge area in dentistry should be targeted to know and indicate biocompatible therapies, aiming at repair processes and providing the natural and biological pulp regeneration. The recent advancement in the cellular and molecular field provided a better understanding of the alterations and behavior of the pulp tissue during the tissue repair process, enabling to biologically evaluate the different strategies for pulp therapy. Notwithstanding, few evidences demonstrate that LLLT would have a directly influence on SHED.

In summary, the present results showed that LLLT using different energy densities has a positive influence on the in vitro viability and proliferation rates of SHED and may be a useful tool for tissue engineering using stem cells. However, further studies are needed to standardize the laser parameters to improve the yield of cells in culture as SHED. The biostimulation of dental pulp stem cells might be an important tool for regenerative therapy and tissue engineering ${ }^{1,14}$.

\section{CONCLUSION}

The Low-Level Laser Therapy energy densities used in this study did not cause loss of cell viability and stimulated SHED proliferation within the parameters described in this study.

\section{REFERENCES}

1- AlGhamdi KM, Kumar A, Moussa NA. Low-level laser therapy: a useful technique for enhancing the proliferation of various cultured cells. Lasers Med Sci. 2012;27(1):237-49.

2- Almeida-Lopes L, Rigau J, Zângaro RA, Guidugli-Neto J, Jaeger MM. Comparison of the low level laser therapy effects on cultured human gingival fibroblasts proliferation using different irradiance and same fluence. Lasers Surg Med. 2001;29:179-84.

3- Azevedo LH, Paula Eduardo F, Moreira MS, Paula Eduardo C, Marques MM. Influence of different power densities of LILT on cultured human fibroblast growth: a pilot study. Lasers Med Sci. 2006;21:86-9.

4- Barboza CA, Ginani F, Soares DM, Henriques AC, Freitas RA. Low-level laser irradiation induces in vitro proliferation of mesenchymal stem cells. Einstein (Sao Paulo). 2014;12(1):75-81. 5- Basso FG, Pansani TN, Turrioni AP, Bagnato VS, Hebling J, Souza Costa CA. In vitro wound healing improvement by low-level laser therapy application in cultured gingival fibroblasts. Int J Dent. 2012;2012:719452.

6- Benedicenti S, Mario Pepe I, Angiero F, Benedicenti A. Intracellular ATP level increases in lymphocytes irradiated with infrared laser light of wavelength $904 \mathrm{~nm}$. Photomed Laser Surg. $2008 ; 26: 451-3$. 
7- Cheng CC, Lee YH, Lin SP, Huangfu WC, Liu IH. Cell-autonomous heparanase modulates self-renewal and migration in bone marrowderived mesenchymal stem cells. J Biomed Sci. 2014;21:21.

8- Cordeiro MM, Dong Z, Kaneko T, Zhang Z, Miyazawa M, Shi S, et al. Dental pulp tissue engineering with stem cells from exfoliated deciduous teeth. J Endod. 2008;34:962-9.

9- Damante CA, De Micheli G, Miyagi SPH, Feist IS, Marques MM. Effect of laser phototherapy on the release of fibroblast growth factors by human gingival fibroblasts. LasersMed Sci. 2009;24:885-91.

10- Eduardo FP, Bueno DF, Freitas PM, Marques MM, PassosBueno $M R$, Eduardo $C P$, et al. Stem cell proliferation under low intensity laser irradiation: a preliminary study. Lasers Surg Med. 2008;40:433-8.

11- Eduardo FP, Mehnert DU, Monezi TA, Zezell DM, Schubert MM, Eduardo $\mathrm{CP}$, et al. Cultured epithelial cells response to phototherapy with low-intensity laser. Lasers Surg Med. 2007;39:365-72.

12- Ferreira MP, Ferrari RA, Gravalos ED, Martins MD, Bussadori SK, Gonzalez DA, et al. Effect of low-energy gallium-aluminumarsenide and aluminium gallium indium phosphide laser irradiation on the viability of $\mathrm{C} 2 \mathrm{C} 12$ myoblasts in a muscle injury model. Photomed Laser Surg. 2009;27(6):901-6.

13- Fujihara NA, Hiraki KR, Marque MM. Irradiation at $780 \mathrm{~nm}$ increases proliferation rate of osteoblasts independently of dexamethasone presence. Lasers Surg Med. 2006;38:332-6.

14- Ginani F, Soares DM, Barreto MP, Barboza CA. Effect of lowlevel laser therapy on mesenchymal stem cell proliferation: a systematic review. Lasers Med Sci. 2015;30:2189-94.

15- Hawkins D, Abrahamse H. Effect of multiple exposures of lowlevel laser therapy on the cellular responses of wounded human skin fibroblasts. Photomed Laser Surg. 2006;24:705-14.

16- Iohara K, Nakashima $M$, Ito $M$, Ishikawa $M$, Nakasima $A$, Akamine A. Dentin regeneration by dental pulp stem cell therapy with recombinant human bone morphogenetic protein 2. J Dent Res. 2004;83:590-5.

17- Karu TI. Photobiological fundamentals of low-power laser therapy. IEEE J Quantum Electron. 1987;23:1703-17.

18- Keepers YP, Pizao PE, Peters GJ, van Ark-Otte J, Winograd $B$, Pinedo HM. Comparison of the sulforhodamine B protein and tetrazolium (MTT) assays for in vitro chemosensitivity testing. Eur J Cancer. 1991;27:897-900.
19- Marques MM, Pereira AN, Fujihara NA, Nogueira FN, Eduardo CP. Effect of lowpower laser irradiation on protein synthesis and ultrastructure of human gingival fibroblasts. Lasers Surg Med. 2004;34:260-5.

20- Miura M, Gronthos S, Zhao M, Lu B, Fisher LW, Robey PG, et al. SHED: stem cells from human exfoliated deciduous teeth. Proc Natl Acad Sci U S A. 2003;100:5807-12.

21- Moore P, Ridgway TD, Higbee RG, Howard EW, Lucroy MD. Effect of wavelength on low-intensity laser irradiation-stimulated cell proliferation in vitro. Lasers Surg Med. 2005;36:8-12.

22- Mvula B, Moore TJ, Abrahamse H. Effect of low-level laser irradiation and epidermal growth factor on adult human adipose derived stem cells. Lasers Med Sci. 2010;25:33-9.

23- Nakashima M, Reddi AH. The application of bone morphogenetic proteins to dental tissue engineering. Nat Biotechnol. 2003;21:1025-32.

24- Pereira AN, Eduardo CP, Matson E, Marques MM. Effect of lowpower laser irradiation on cell growth and procollagen synthesis of cultured fibroblasts. Lasers Surg Med. 2002;31:263-7.

25- Pourzarandian A, Watanabe H, Ruwanpura SM, Aoki A, Ishikawa I. Effect of low-level Er:YAG laser irradiation on cultured human gingival fibroblasts. J Periodontol. 2005;76:187-93.

26- Sakai VT, Zhang Z, Dong Z, Neiva KG, Machado MA, Shi S, et al. SHED differentiate into functional odontoblasts and endothelium. J Dent Res. 2010;89:791-6.

27- Soares DM, Ginani F, Henriques AG, Barboza CA. Effects of laser therapy on the proliferation of human periodontal ligament stem cells. Lasers Med Sci. 2015;30(3):1171-4.

28- Stein A, Benayahu D, Maltz L, Oron U. Low-level laser irradiation promotes proliferation and differentiation of human osteoblasts in vitro. Photomed Laser Surg. 2005;23:161-6.

29- Volpato LE, Oliveira RC, Espinosa MM, Bagnato VS, Machado MA. Viability of fibroblasts cultured under nutritional stress irradiated with red laser, infrared laser, and red light-emitting diode. J Biomed Opt. 2011;16:075004.

30- Wu YH, Wang J, Gong DX, Gu HY, Hu SS, Zhang H. Effects of low-level laser irradiation on mesenchymal stem cell proliferation: a microarray analysis. Lasers Med Sci. 2012;27:509-19. 